\title{
GENETIC VARIABILITY IN POPULATIONS OF Agave sisalana PERRINE DETECTED BY INTER SIMPLE SEQUENCE REPEATS
}

\author{
VARIABILIDADE GENÉTICA EM POPULAÇÕES DE Agave sisalana PERRINE \\ DETECTADA PELA TÉCNICA INTER SIMPLE SEQUENCE REPEATS
}

\section{Silvia Letícia Bispo dos SANTOS ${ }^{1}$; Adriana Rodrigues PASSOS ${ }^{2}$; Sandra Regina de Oliveira Domingos QUEIROZ ${ }^{3}$; Marilza Neves do NASCIMENTO ${ }^{4}$; Fernando dos Santos CARNEIRO 5}

1. Bióloga, Universidade Estadual de Feira de Santana - UEFS, Feira de Santana, BA, Brasil. silvialetsan@ @hotmail.com; 2. Professora, Doutora, Programa de Pós Graduação em Recursos Genéticos Vegetais - UEFS, Feira de Santana, BA, Brasil; 3. Pesquisadora Bolsista do Centro de Pesquisas do Cacau - CEPLAC/BA, Ilhéus, BA, Brasil; 4. Professora, Doutora, Programa de Pós Graduação em Recursos Genéticos Vegetais - UEFS, Feira de Santana, BA, Brasil; 5. Mestre em Recursos Genéticos Vegetais, Universidade Estadual de Feira de Santana - UEFS, Feira de Santana, BA, Brasil.

\begin{abstract}
The aim this work was to evaluate the genetic variability within and among populations grown on sisal region of Bahia. The genetic diversity of 140 population of sisal was analyzed using ISSR molecular markers. Samples were collected in six counties in Bahia. Eighteen primers of ISSR were used, in which nine of them were effective in the amplification of DNA samples to yield 143 polymorphic loci. The average percentage of polymorphism found in the population was 64\%. The average heterozygosis (He) and Shannon-Wiener index (I) were 0.180 and 0.279 , respectively. $73 \%$ of the molecular variance can be due to intrapopulation differences. The populations were divided into two groups according to their geographical location, showing a structure of genetic variability in space. The GST 0.235 , enough to avoid that there is a strong population differentiation. The genetic structure of sisal can be exploited for the creation of gene banks for conservation in situ and ex situ to obtain individuals of good commercial quality. There is genetic variability among sisal genotypes. ISSR molecular markers are efficient to analyze the divergence between sisal genotypes, assisting improvement work.
\end{abstract}

KEYWORDS: Sisal. Genetic diversity. ISSR. Molecular markers.

\section{INTRODUCTION}

The sisal (Agave sisalana Perrine) is a species eminently tropical, encompassing a welldefined group of herbaceous consistency plants and protruding floral scape, reaching twelve or more feet tall (SILVA; BELTRÃO, 1999). Its main use is the extraction of fibers contained in their leaves, bringing forth to the main hard fiber produced in the world, contributing with over half of all commercial production of such fibers (EMBRAPA, 2010).

Brazil is the largest producer of sisal in the world, and the states of Bahia, Paraíba, Ceará and Rio Grande do Norte figure as top producers. In Paraíba Sisal is the main exportation product and in 2013 Bahia stood out in the national ranking (SEAGRI, 2014).

The population genetics has been used as an important tool in the study of genetic diversity, describing variability and studying the mechanisms of maintenance of this variability (NEI, 1987). Because it is an important species, generating income for the population of semi-arid of Bahia, it was necessary to know the genetic behavior of populations of sisal, molecularly classifying samples, favoring the selection of individuals that represent the genetic diversity, establishing standards for differentiation.

The use of molecular genetic techniques is of fundamental importance for the study of genetic variability in a population. The genetic variability of Agaves have been studied using different molecular markers, including: isoenzymes in A. fourcroydes Lem. (COLUNGA-GARCÍAMARÍM et al., 1999), A. victoriae-reginae (MARTÍNEZ-PALACIOS et al., 1999) and A. lechuguilla Torr. (SILVAMONTELLANO; EGUIARTE, 2003); Microsatellite cupreata and $A$. potatorum (EGUIARTE et al., 2003); RAPD in tequilana Weber Agave (GIL-VEGA et al., 2004, 2006) and A. deserti (NAVARRO-QUEZADA et al., 2003); AFLP in A. fourcroydes Lem. (GONZALEZ et al., 2003; DEMEY et al., 2004) and A. angustifolia Haw. (BARRAZA-MORALES et al., 2006; TEYER-SÁNCHEZ et al., 2009) and ISSR in $A$. angustifolia and A. tequilana (VARGAS-PONCE et al., 2009).

Considering the economic importance of sisal for the semi-arid region of Bahia, and taking into account that the main form of reproduction is vegetative growing in the region, and the fact that there are no studies using molecular markers for 
identification of genetic variability in Agave sisalana, the investigation of genetic variability of the populations this species from plants collected in six counties of the sisal region of Bahia state, using the marker Inter Simple Sequence Repeats (ISSR) was aim of this study.

\section{MATERIAL AND METHODS}

The survey was conducted in the semiarid areas of Bahia, in the counties of Jacobina (JAC), Campo Formoso (CF), Valente (VAL), São Domingos (SD), Santaluz (STL) and Ourolândia (OUR), where we collected 25 individuals randomly from a single population. The initial sample consisted of 150 genotypes (Table 1).

Immediately after collection, the materials were taken to the Laboratory of Molecular Systematics of Plants (LAMOL) State University of Feira de Santana-BA (UEFS), where all experimental steps were performed.
SANTOS, S. L. B. et al.

For DNA extraction from fresh material, the protocol followed was Doyle and Doyle (1987) making adaptations to microtubes replacing the tubes.

18 Primers were tested by a PCR reaction on six individuals, one from each population, chosen at random, to verify the amplification profile. The display of each primer was taken after agarose gel electrophoresis. Of the 18 ISSR primers tested, nine showed greater variability indices, and were then used in the experiment.

The DNA amplifications were performed in accordance with the following thermocycler conditions: $94{ }^{\circ} \mathrm{C}$ for 1.5 minutes Pre-melt, then 35 cycles of amplification. In each cycle steps were 94 ${ }^{\circ} \mathrm{C}$ for 40 seconds for denaturation, annealing at 46 ${ }^{\circ} \mathrm{C}$ for 45 seconds and extension $72{ }^{\circ} \mathrm{C}$ for 1.5 minutes. After the cycles, the samples were maintained at $72{ }^{\circ} \mathrm{C}$ for 7 minutes for the final extension.

Table 1. Geographical coordinates and altitudes of the collection sites of the six populations of sisal ( Agave sisalana) grown in the state of Bahia.

\begin{tabular}{|c|c|c|c|}
\hline Municipalities & $\begin{array}{l}\text { Number of individuals by } \\
\text { county }\end{array}$ & $\begin{array}{l}\text { Geographical } \\
\text { coordinates }\end{array}$ & Altitude (m) \\
\hline Jacobina (JAC) & 25 & $\begin{array}{l}\text { S } 11^{\circ} 01^{\prime} 19,4^{\prime \prime} \\
\text { W } 40^{\circ} 46^{\prime} 07,6^{\prime}\end{array}$ & 742 \\
\hline Campo Formoso (CF) & 25 & $\begin{array}{l}\mathrm{S} 11^{\circ} 25^{\prime} 49,5^{\prime}, \\
\text { W } 40^{\circ} 35^{\prime} 38,8^{\prime}\end{array}$ & 580 \\
\hline Valente (VAL) & 25 & $\begin{array}{l}\text { S } 11^{\circ} 20^{\prime} 29,3^{\prime \prime} \\
\text { W } 39^{\circ} 27^{\prime} 30,3^{\prime \prime}\end{array}$ & 358 \\
\hline São Domingos (SD) & 25 & $\begin{array}{l}\mathrm{S} 11^{\circ} 27^{\prime} 56^{\prime}, \\
\text { W } 39^{\circ} 31^{\prime} 34^{\prime},\end{array}$ & 310 \\
\hline Santaluz (STL) & 25 & $\begin{array}{l}\mathrm{S} 11^{\circ} 15^{\prime} 21^{\prime}, \\
\text { W } 39^{\circ} 22^{\prime} 29^{\prime},\end{array}$ & 370 \\
\hline Ourolândia (OUR) & 25 & $\begin{array}{l}\text { S } 10^{\circ} 48^{\prime} 09.0^{\prime \prime} \\
\text { W } 41^{\circ} 16^{\prime} 11,9^{\prime},\end{array}$ & 667 \\
\hline
\end{tabular}

Each amplification mix was composed of buffer regulator $10 \mathrm{X}, \mathrm{MgCl}_{2}(1.25 \mathrm{mM})$; DNTP $(1.25 \mathrm{mM}), 10$ pmol primer; additive Betaine $(0.005$
$\mathrm{mM}$ ), Taq DNA polymerase (5U); $\mathrm{H}_{2} \mathrm{O}$ (qs) and 0,8 microlitres of total DNA with concentration of 80ng. 
The data were entered into the GelCompar II version 5.1 (Applied Maths, USA), which made the analysis and association between all gels of different primers for all populations, thus obtaining an array of binary values zero and one, relating absence or presence of selected markers in different loci in six populations of Agave sisalana.

The amplified bands in base pairs had the size of fragments estimated by comparing them with the 100 bp ladder marker. From the results, a binary array was built by GelCompar II program, noting the presence of bands within a unique population or populations, the number and percentage of polymorphic bands for primers, thereby determining the amount of each polymorphic loci population.

The analysis of the genetic profiles of the data allowed an estimation of variance components attributed to differences between the six populations, regions and individuals within regions using the similarity coefficient of Jaccard (1908), through programs GenAlEx (PEAKALL; SMOUSE, 2006), PopGene 1.31 (YEH et al., 1999) and Structure 2.3.3 (PRITCHARD et al., 2000).

The similarity matrix constructed from the Jaccard index was applied to cluster analysis by the method of the arithmetic averages of groups unweighted UPGMA - Unweighted Pair Group Method with Arithmetic Mean and used to construct a dendrogram.

As recommended by the UPGMA method, we considered the six populations, which were grouped in succession, based on proximity.

The program PopGene (Population Genetic Analisys) Version 1.31 (YEH et al., 1999) was used to estimate allele frequencies from the following parameters of Genetic Diversity: Shannon-Wiener index (I), Heterozigosity Expected (He), intrapopulation genetic differentiation (GST), percentage of polymorphic loci $(\mathrm{P} \%)$ and number of migrants (Nm) (NEI, 1973); Genetic Distance (NEI, 1978) and number of alleles per Loco.

Genetic differentiation and distribution of genetic variability among and within species was estimated by Analysis of Molecular Variance (AMOVA) (EXCOFFIER et al., 1992) using the program PopGene, version 1.31 (YEH et al., 1999). The variance components used were $\square_{\text {ST }}$ analogous to $G_{S T}$, estimated the genetic variability that exists between people and their significance, considering the set as a whole, the $\square_{\mathrm{PR}}$ estimates diversity among populations, the $\square_{\mathrm{PR}}$ estimates of the diversity within and between populations and $\square_{\mathrm{RT}}$ which measures only the diversity between regions.

Allele frequencies were estimated at $\mathrm{q}=$ square root of the frequency of ' 0 'phenotypes, using the correction (LYNCH; MILLIGAN, 1994), applied by AFLPsurv software (VEKEMANS, 2002).

The software AFLPsurv produced arrays of pairs of genetic distances between populations (with bootstraps) and coefficients of relatedness between individuals in pairs, doing multiple tests of significance based on permutation (VEKEMANS, 2002).

The calculation of genetic linkage between pairs of individuals through genetic linkage estimator (rxy) of Ritland (1996) done with the program GenAlEx 6.0, made it possible to measure the proportion of alleles identical by descent between two individuals.

The program also calculated the effective number of alleles (Ae), ie those who actually pass to the next generation (PEAKALL; SMOUSE, 2006), and was also used to make principal coordinate analysis (PCoA) and the results were plotted using Microsoft Excel 2007 software.

\section{RESULTS AND DISCUSSION}

The primers used generated a total of 143 bands, ranging from 13 to 19 primer. Of the 143 loci obtained, 136 were polymorphic (95.1\%). The percentage of polymorphic loci (\% $\mathrm{P})$ ranged from $57.34 \%$ in populations of CF and STL to $82.52 \%$ in the population of VAL. The average polymorphic loci in populations were $63.63 \%$ (Table 1). These results comply with the criterion of $95 \%$ of polymorphism frequency adopted by software. The expected heterozygosis (He) ranging from populations, 0.150 (STL) at 0.259 (NPV) with a mean value of 0.180 . The expected heterozygosis (He) showed no significant difference between the populations. For the Shannon index (I), was also not significantly different, the values ranged from 0 . 235 (STL) to 0.394 (VAL), the average for this index was: $I=0.279$. Bands were observed in specific populations and VAL and OUR (Table 2). In this work we found levels of expected heterozygosity relatively high, both for analysis at the species level for total and average populations. The values found in this study are similar to those found by other authors for other Agaves using ISSR technique (Eguiarte et al. 2003; González-Astorga et al., 2004).

The clustering observed in Figure 1 demonstrates the clustering structure that indicates the existence of two groups gathering the sample populations. In the first group populations $\mathrm{CF}$ and CR are grouped with high support (100\% bootstrap), and then connected to the OUR population (94\% 
BS). The other group includes populations NPV, and SD (STL BS 100\%), but the relationship between them proved ill-defined because the support pool among populations and SD VAL is low $(65 \%)$.

Table 2. Genetic diversity of six populations of Agave sisalana semiarid Bahia, on nine ISSR markers.

\begin{tabular}{lllllc}
\hline Genetic diversity & \multicolumn{5}{l}{} \\
\hline Population & $\% P$ & $H e$ & $I$ & $A e$ & $\mathrm{~N}^{\circ}$ of private bands* \\
\hline JAC & 59.44 & 0.167 & 0.258 & 1.276 & 0 \\
CF & 57.34 & 0.164 & 0.254 & 1.269 & 0 \\
VAL & 82.52 & 0.259 & 0.394 & 1.437 & 3 \\
SD & 59.44 & 0.167 & 0.261 & 1.267 & 0 \\
STL & 57.34 & 0.150 & 0.235 & 1.246 & 0 \\
OUR & 65.73 & 0.175 & 0.273 & 1.281 & 4 \\
\hline Average (\%) & 63.63 & 0.180 & 0.279 & 1.296 & 1.16 \\
\hline
\end{tabular}

$\mathrm{P}=$ percentage of polymorphic loci, He = expected heterozygosity, I = Shannon Index; Ae - effective alleles. JAC - Jacobina, CF - Campo Formoso; VAL - Valente, SD - São Domingos; STL - Santaluz; OUR - Ourolândia. * there are individuals who belong to different taxa.

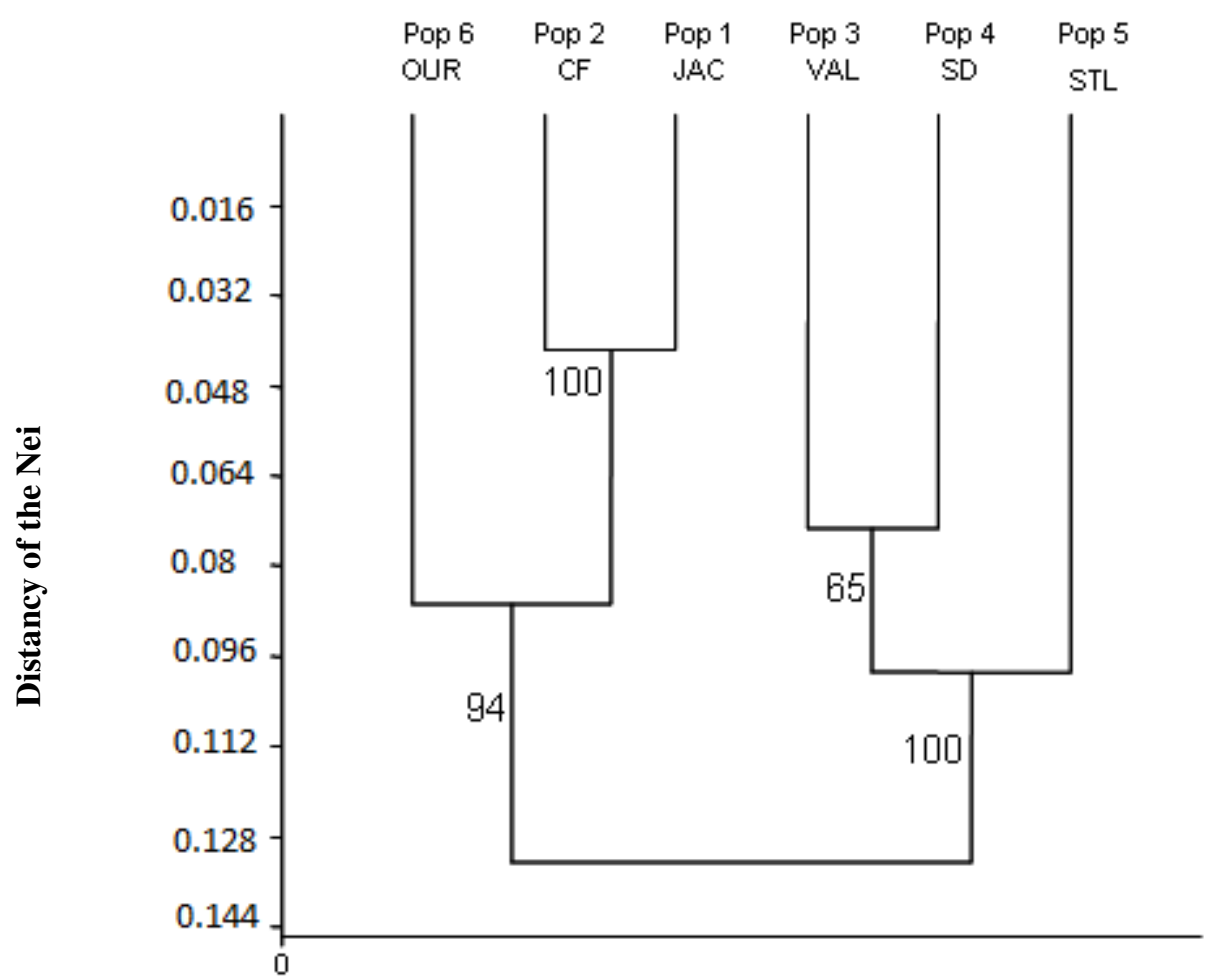

Figure 1. Dendrogram showing the phenetic relationships among populations of Agave sisalana six localities of Bahia Jacobina (JAC), Campo Formoso (CF), Valente (VAL), São Domingos (SD), Santaluz (STL) and Ourolândia (OUR), with based on UPGMA.

In Figures 2 and 3 are presented the principal coordinate analysis (PCoA) of all individuals of the populations, indicating the percentage of variance explained by the first three axes. The three coordinates explain $14.00 \%, 8.69 \%$ and $6.61 \%$ of genetic variation, respectively.
The first axis (14.00\%) shows a clear separation of the two groups, although there is a small overlap of a few individuals. The first group was composed of populations $\mathrm{CR}, \mathrm{CF}$, OUR, and the same are positively correlated with the axis, the second group of the populations VAL, SD, and STL 
(Figure 3) is negatively associated with this axle. In the second axis (8.69\%) is possible to notice a light separation within the first group among the three populations.

The third axis $(6.61 \%)$ also allowed within the group 2, the separation of the population of OUR, JAC, CF (Figure 3). The remaining percentage changes in subsequent axes are the differences among individuals within populations.

The groups of populations were consistent with their geographical origin. Populations were separated according to the territories of identity proposed by the state government. Populations of
SANTOS, S. L. B. et al.

JAC, CF and OUR, called group 1, are located in the territory of the Diamantina Piedmont Identity; populations VAL, SD and STL, called group 2, are located in the territory of Sisal Identity.

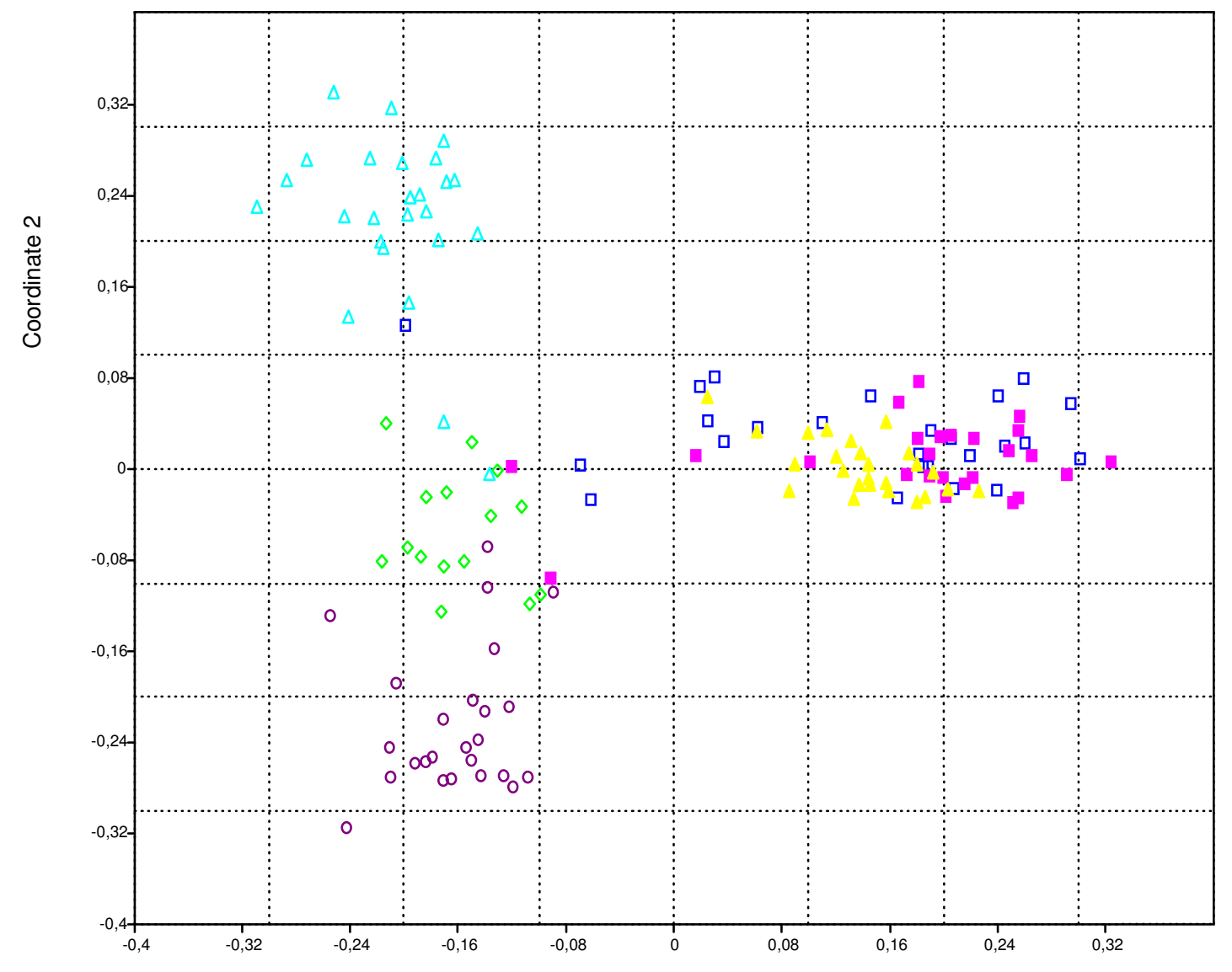

Coordinate 1

\section{JAC $\square 2$ CF $\square$ 3 VAL $\bigcirc 4$ SD $\ 5$ STL $\triangle 6$ OUR}

Figure 2. Principal coordinates analysis (PCoA) of populations of Agave sisalana from six localities of Bahia: Jacobina (JAC), Campo Formoso (CF), Valente (VAL), São Domingos (SD), Santaluz (STL) and Ourolândia (OUR). Axis 1 x 2 corresponding to $22.69 \%$. 


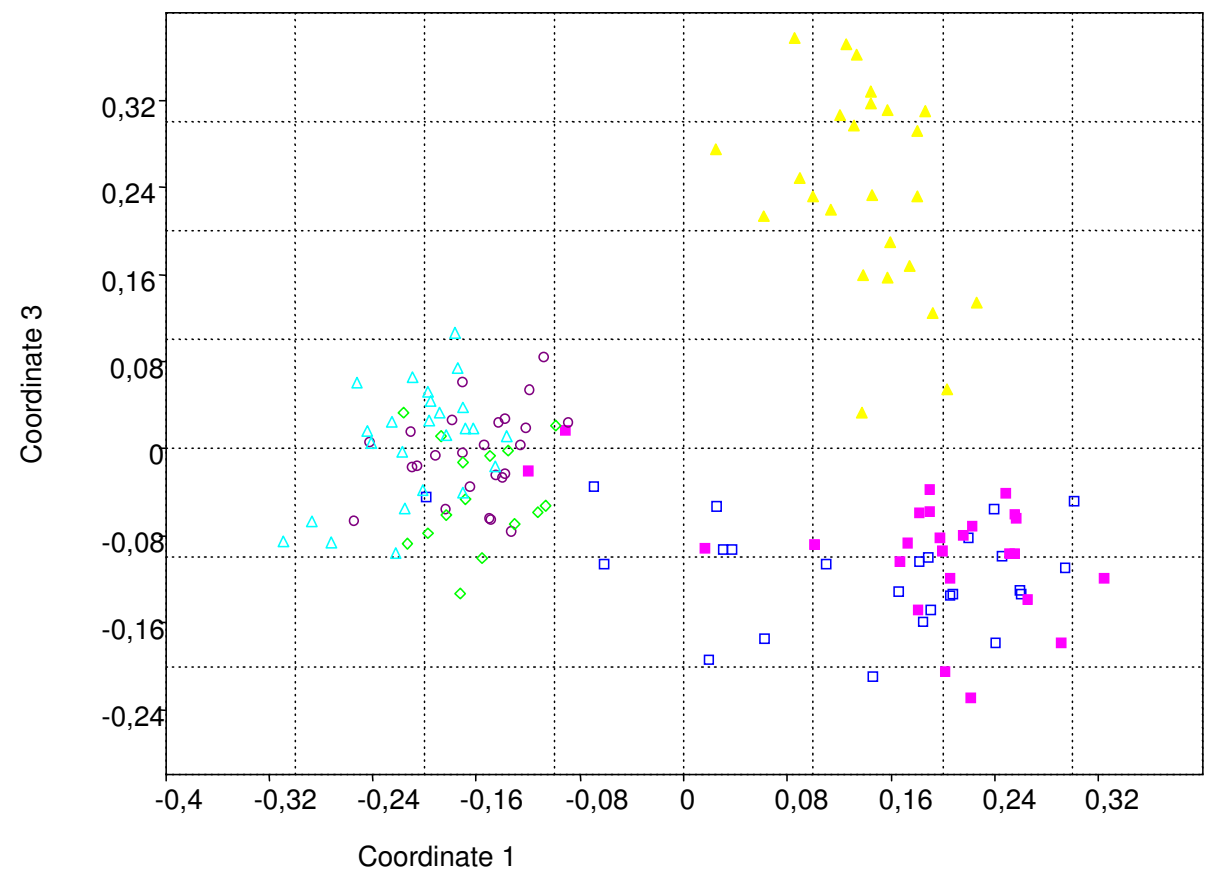

\section{$1 \mathrm{JAC} \square 2 \mathrm{CF} \square 3 \mathrm{VAL} \bigcirc 4 \mathrm{SD} \backslash 5 \mathrm{STL} \backslash 6 \mathrm{OUR}$}

Figure 3. Principal coordinate analysis ( $\mathrm{PCoA})$ of populations of Agave sisalana six localities of Bahia Jacobina (JAC), Campo Formoso (CF), Valente (VAL), São Domingos (SD), Santaluz (STL) and Ourolândia (OUR). Axis 1 x 3, corresponding to $20.61 \%$.

The results obtained from the cluster analysis showed that the genetic distances within the groups are smaller, which can be explained by the smaller distance among populations that form each group. The trend of people from getting together according to their geographic location shows a spatial structure of variability.

Genetic diversity obtained was significant $(\mathrm{P}<0.001)$ within populations. From the total genetic variance found for the molecular species, $27.00 \%$ is due to differences between populations, while $73.00 \%$ is attributed to differences between individuals.

The analysis of molecular variance of populations, taking into account subdivision between regions $(11.44 \%)$, among populations $(18.11 \%)$ and within populations (70.44\%) confirmed the variability (Table 3 ).

The average values of $\mathrm{G}_{\mathrm{ST}}$ and $\mathrm{Nm}$ that were found to populations were 0.235 and 1.63, respectively. Considering the two population groups produced by cluster analysis, it appears that group 1 showed GST and $\mathrm{Nm}$ equal to $0.145,2.96$, and group 2 was respectively $0.172,2.41$. The level of total heterozygosis (Ht) for analysis to the species level (global) was 0.236. Group 2 had an average heterozygosis of 0.192 , higher than the 0.169 group (Table 4).

Table 3. Summary of analysis of molecular variance (AMOVA) for the six populations of the Agave sisalana.

\begin{tabular}{llll}
\hline Population & FV & \% Total & Statistiscs \\
\hline \multirow{2}{*}{ All } & Among populations & 27.00 & $\square_{\mathrm{PT}}=0.272^{* *}$ \\
& Inside populations & 73.00 & \\
\hline \multirow{3}{*}{ All } & Among regions & 11.44 & $\square_{\mathrm{RT}}=0.114^{* *}$ \\
& Among populations & 18.11 & $\square_{\mathrm{PR}}=0.205^{* *}$ \\
& Inside de populations & 70.44 & $\square_{\mathrm{PT}}=0.296^{* *}$ \\
\hline
\end{tabular}


Table 4. $\mathrm{G}_{S T}$ values, Nm, Ht and Hs for the six populations of the Agave sisalana studied and the two groups of populations.

\begin{tabular}{lllll}
\hline Populações & $G_{S T}$ & $N m$ & $H t$ & $H s$ \\
\hline All & 0.235 & 1.63 & 0.236 & 0.180 \\
Group 1 & 0.145 & 2.96 & 0.197 & 0.169 \\
Group 2 & 0.172 & 2.41 & 0.232 & 0.192
\end{tabular}

Group 1 - Populations (Jacobina; Campo Formoso and Ourolândia), Group 2 - Populations (Valente; São Domingos and Santaluz). $\mathrm{Nm}=0.5\left(1-\mathrm{G}_{S T}\right) / \mathrm{G}_{S T}$.

In studies conducted by Gonzalez-Astorga et al. (2004), in Agave-garciae mendozae, it was observed that $86.05 \%$ of the variation occurred within populations and $2.64 \%$ diversity between regions, suggesting that this species of Agave is isolation by distance.

In this work, the total genetic diversity detected in each population, indicated that the population of Valente has greater diversity among six populations analyzed, then the population of Jacobina. This can be seen both by the percentage of polymorphic bands, and through the diversity index of Shannon-Wiener. This greater diversity observed for the population of Valente may have started with transporting seedlings for farmers and currently maintained on behalf of reproductive mode.

The values obtained show high levels of genetic diversity within populations of Agave sisalana. These values showed the same pattern as those proposed by Nybom (2004) assessing the diversity among and within populations of angiosperms and gymnosperms.

Plant species differ markedly as to how genetic diversity is partitioned among populations. The splitting pattern is correlated with breeding systems and life-history parameters (Hamrick and Godt, 1989). Species which are especially long term as is the case.

Agave sisalana, present a higher genetic diversity within the population than in between. In the present study we observed that the two population groups were formed taking into account the altitude.

In species that reproduce preferably by cross-fertilization, it is generally expected to find high diversity within populations and low divergence between populations. The opposite is expected for species that reproduce preferentially selfing (LOVELESS; HAMRICK, 1984; HAMRICK; GODT, 1996). This may indicate a supposed outcrossing for sisal.

Genetic differentiation of A. sisalana compared with values obtained in other species
ISSR demonstrated that they are genetically close. For example, A. sisalana $\left(\square_{\mathrm{ST}}=0.12\right)$, A. cupreata $\left(\square_{\mathrm{ST}}=0.14\right)$, A. potatorum $\left(\square_{\mathrm{ST}}=0: 08\right)$ (Eguiarte et al., 2003) and A.-garciae mendozae $(\square \mathrm{ST}=0 \quad 10)$ (González \& Hamrick, 2005).

Results from RAPD in Agaveceae were similar to those found with ISSR; A cerulata $\left(\square_{\mathrm{ST}}=\right.$ $0.10)$, A. subsimplex $\left(\square \square_{\mathrm{ST}}=0.08\right)$, and $A$. deserti $\left(\square_{\mathrm{ST}}=0.14\right)$ (Navarro-Quezada et al., 2003). In the case of A. lechuguilla $\left(\square_{\mathrm{ST}}=0.083\right)$ (SilvaMontellano; Eguiarte, 2003), results obtained using isoenzymes indicated low genetic variation. However, this results are much lower than those presented in A. subsimplex $\left(\square_{\mathrm{ST}}=0.31\right)$ and $A$. victoriae-reginae $\left(\square_{\mathrm{ST}}=0.33\right)$ using isoenzymes (Martinez-Palacios et al., 1999). Comparing with long-lived perennials Nybom (2004), found $\square_{\mathrm{ST}}$ and $\mathrm{G}_{\mathrm{ST}}$ of 0.25 and 0.19 , respectively.

Comparisons of results obtained in this work with the literature confirmed the validation of the number of polymorphic loci and primers needed for the development of a working population genetics, producing reliable results.

As ISSRs are dominant multilocus markers, the use of a small number of primers is sufficient to provide information relevant to the study of polymorphisms within and among populations of plants (Xia et al., 2007).

\section{CONCLUSIONS}

The ISSR molecular markers were effective to separate the genotypes studied and a wide variability for the species was observed. The variation within populations $(73.00 \%)$ was higher than that genetic variation interpopulational $(27.00 \%)$.

These results add new information on the genetic diversity in A.sisalana, thus contributing to the biological knowledge of the species and providing insights for future breeding and conservative programs. 
RESUMO: O objetivo deste trabalho foi avaliar a variabilidade genética existente entre e dentro das populações cultivadas na região sisaleira baiana. A diversidade genética de 140 indivíduos de sisal foi analisada por meio de marcadores moleculares ISSR. As amostras foram coletadas em seis municípios baianos. Utilizando-se dezoito primers de ISSR, dos quais, nove foram eficientes na amplificação do DNA das amostras analisadas, obtendo-se 143 locos polimórficos. O percentual médio de polimorfismo encontrado nas populações foi de $64 \%$. A média de heterozigosidade (He) e do índice de Shannon-Wiener (I) foram de 0,180 e 0,279, respectivamente. 73\% da variância molecular pode ser atribuída às diferenças intrapopulacionais. As populações foram divididas em dois grupos, de acordo com sua localização geográfica, evidenciando uma estruturação da variabilidade genética no espaço. $\mathrm{O} G_{S T}$ de 0,235 foi suficiente para evitar que exista uma forte diferenciação populacional. A estruturação genética do sisal pode ser explorada para a criação de bancos de germoplasma, visando à conservação in situ e ex situ, para a obtenção de indivíduos de boa qualidade comercial. Há presença de variabilidade genética entre os genótipos de sisal. Marcadores moleculares ISSR são eficientes para analisar a divergência entre os acessos de sisal, auxiliando trabalhos de melhoramento.

PALAVRAS CHAVE: Sisal. diversidade genética. marcadores moleculares ISSR.

\section{REFERENCES}

COLUNGA-GARCÍAMARÍN, P.; COELLO-COELLO, J.; EGUIARTE, L.; PIÑERO, D. Isoenzymatic variation and phylogenetic relations between henequén Agave fourcroydes Lem. and its wild ancestor Agave angustifolia Haw. American Journal of Botany, Saint Louis, v. 86, n. 1, p. 115-123. 1999. http://dx.doi.org/10.2307/2656960

DEMEY, J. R.; GAMEZ, E.; MOLINA S.; INFANTE, D. Comparative study of the discriminating capacity of AFLP and ISTR markers for genetic analysis of Agave fourcroydes. Plant Molecular Biology Reporter, Melbourne, v. 22, p. 29-35. 2004. http://dx.doi.org/10.1007/BF02773346

DOYLE, J. J.; DOYLE, J. L. A rapid DNA isolation procedure for small quantities of fresh leaf tissue. Phytochemical Bulletin, Irvine, v. 19, p. 11-15. 1987.

EGUIARTE, L. E. F.; DUGUA, X. A.; MUNIVE, M. R.; DÍAZ, C. T.; MONTELLANO A. S.; VÁZQUEZ, A. V. Diversidad Genetica en dos Especies Mezcaleras. Proyecto Conabio. México, DF. v. 38. 2003. 33p.

EMBRAPA. Empresa Brasileira de Pesquisa Agropecuária. Informações gerais sobre o sisal. Disponível em: $<$ http://www.cnpa.embrapa.br/ - Acessado em: 25 de abril de 2010.

EXCOFFIER, L.; SMOUSE, P. E.; QUATTRO, J. M. Analysis of molecular variance inferred from metric distances among DNA haplotypes: application to human mitochondrial DNA restriction data. Genetics, Bethesda, v. 131, p. 479-491. 1992.

GONZÁLEZ-ASTORGA, A. M.; ROCHA, A.; VALERA, Y. L. EGUIARTE. Genética de poblaciones y ecología reproductiva del Agave garciae-mendozae. IV Simpósio Internacional sobre Agavaceae y Nolinaceae. Yucatán. México, 21 p. 2004.

GONZÁLEZ, G.; ALEMÁN, S.; INFANTE, D. Asexual genetic variability in Agave fourcroydes II: selection among individuals in a clonally propagated population. Plant Science, Kansas, v. 165, p. 595-601. 2003. http://dx.doi.org/10.1016/S0168-9452(03)00227-9

HAMRICK, J. L.; GODT, M. J. W. Allozyme diversity in plant species. In Plant population genetics, breeding and germplasm resource (se d. A. H. D. Brown, M. T. Clegg, A. L. Kahler \& B. S. Weir). Sunderland, MA: Sinauer. pp. 43-63. 1989.

HAMRICK, J. L.; GODT, M. J. W. Effects of life history traits on genetic diversity in plant species. Plant Life Histories. Ecological Correlates and Phylogenetic Constraints. Philosophical Transactions: Biological Sciences, London, v. 351, p. 1291-1298. 1996. http://dx.doi.org/10.1098/rstb.1996.0112 
JACCARD, P. Nouvelles recherches sur la distribution florale. Bulletin Société Vaudoise des Sciences Naturelles, Lausanne, v. 44, n. 2, p. 223-270. 1980.

LOVELESS, M. D.; HAMRICK, J. L. Ecological determinants of genetic structure in plant populations. Annual Review of Ecology and Systematics, Palo Alto, v. 15, p. 65-95. 1984.

http://dx.doi.org/10.1146/annurev.es.15.110184.000433

LYNCH, M. Y.; MILLIGAN, B. G. Analysis of population genetic structure with RAPD markers. Molecular Ecology, Vancouver, v. 3, p. 91-99. 1994. http://dx.doi.org/10.1111/j.1365-294X.1994.tb00109.x

MARTÍNEZ-PALACIOS, A.; EGUIARTE, L. E.; FURNIER, Y. G. Genetic diversity of the endangered endemic Agave victoriae-reginae (Agavaceae) in the Chihuahuan desert. American Journal of Botany, Saint Louis, v. 86, p. 1093-1098. 1999. http://dx.doi.org/10.2307/2656971

NAVARRO-QUEZADA, A.; GONZÁLEZ-CHAUVET, R.; MOLINA-FREANER, F.; EGUIARTE, L. E. Genetic differentiation in the Agave deserti (Agavaceae) complex of the Sonoran desert. Heredity, Cardiff, v. 90, p. 220-227. 2003. http://dx.doi.org/10.1038/sj.hdy.6800216

NEI, M. Analysis of gene diversity in subdivided populations. Proceedings of the National Academy of Sciences of the United States of America, New York, v. 70, p. 3321 - 3323. 1973. http://dx.doi.org/10.1073/pnas.70.12.3321

NEI, M. The theory of genetic distance and evolution of human races. Japanese Journal of Human Genetics, Yokohama, v. 23, p. 341-369. 1978. http://dx.doi.org/10.1007/BF01908190

NEI, M. Molecular evolutionary genetics. Columbia University Press, New York. 1987.

NYBOM, H. Comparison of different nuclear DNA markers for estimating intraspecific genetic diversity in plants. Molecular Ecology, Vancouver, v. 13, p. 1143-1155. 2004. http://dx.doi.org/10.1111/j.1365294X.2004.02141.x

PEAKALL, R.; SMOUSE, P. E. GenAlEx 6: Genetic Analysis in Excel. Population genetics software for teaching and research. Molecular Ecology, Vancouver, v. 6, p. 288-295. 2006.

http://dx.doi.org/10.1111/j.1471-8286.2005.01155.x

PRITCHARD, J. K.; STEPHENS, M.; DONNELLY, P. Inference of population structure using multilocus genotype data. Genetics, Bethesda, v. 155, p. 945-959. 2000.

RITLAND K. Estimators for pairwise relatedness and individual inbreeding coefficients. Genetical Research, Cambridge, v. 67, p. 175-185. 1996. http://dx.doi.org/10.1017/S0016672300033620

SEAGRI. Cultura do Sisal. Disponível em: http://www.bahia.ba.gov.br/seagri - Acesso outubro de 2009.

SILVA, O. R. R. F.; BELTRÃO, N. E. M. O agronegócio do sisal no Brasil. Brasília. DF. Embrapa. 1999. $205 \mathrm{p}$.

SILVA-MONTELLANO, A.; EGUIARTE, E. L. Geographic patterns in the reproductive ecology of Agave lechuguilla (Agavaceae) in the Chihuahuan desert I. Floral characteristics, visitors, and fecundity. American Journal of Botany, Saint Louis, v. 90, p. 700-706. 2003. http://dx.doi.org/10.3732/ajb.90.5.700

VARGAS-PONCE, O.; ZIZUMBO-VILLARREAL, D.; MARTÍNEZ-CASTILLO, J.; COELLO-COELLO, J.; COLUNGA-GARCIAMARÍN, P. Diversity and structure of landraces of Agave grown for spirits under traditional agriculture: A comparison with wild populations of Agave angustifolia (agavaceae) and commercial plantations of Agave tequilana. American Journal of Botany, Saint Louis, v. 96, p. 448-457. 2009. http://dx.doi.org/10.3732/ajb.0800176 
VEKEMANS, X. AFLP-surv version 10. Laboratoire de Génétique et Ecologie Végétale. Université Libre de Bruxelles. Belgium. 2002.

XIA, T.; CHEN, S.; CHEN, S.; ZHANG, D.; GAO, Q.; GE, X. ISSR analysis of genetic diversity of the Qingahai-Tibet Plateau endemic Rhodiola chrysanthemifolia (Crassulaceae). Biochemical Systematics and Ecology, Lowa, v. 35, p. 209-214. 2007.

YEH, F.C.; YANG, R.C.; BOYLE, T. POPGENE. Microsoft Windows-Based Freeware for population genetic analysis, Release 1.31. University of Alberta. Edmonton, Canada. 29p. 1999. 